\title{
Symposium: Reflections Before, During, and Beyond COVID-19
}

\section{Reflections on a Secular Age: Dharmaśāstric and Confucian Social Orderings}

\author{
Jason Morgan ${ }^{1}$ \\ Published online: 27 July 2020 \\ (C) Springer Science+Business Media, LLC, part of Springer Nature 2020
}

\begin{abstract}
The modern world is often described as highly secularized. This secularization can distort our view of the past, and also of societies in which secularization holds less sway than in other places. In this essay, I examine Confucianism and Dharmaśāstra as two paradigms for the study of pre-secular or non-secular societies, comparing and contrasting Confucian and Hindu societies while comparing and contrasting both with the current, "secular age".
\end{abstract}

Keywords Dharmaśāstra · Confucianism · St. Louis IX · Rigveda $\cdot$ Veda $\cdot$ Manu $\cdot$ Hindu law $\cdot$ Secularization $\cdot$ Japan $\cdot$ China India

One of the rare points of agreement among most people of whatever political or religious persuasion is that we live, as Charles Taylor wrote, in a secular age. ${ }^{1}$ It is not only that people are leaving organized religions in droves that affirms this, but the tone of the Zeitgeist itself. The Enlightenment is the idiom of our social interactions. Even the Vatican has become a champion of religious freedom, while other iterations of 1789 and 1776 - human rights, free speech, personal autonomy, self-ownership, and many more - are embedded in institutions once antithetical to such deistic, or even agnostic, conceptions of the human person. ${ }^{2}$ The age is a secular one, and while there is deep division over how the various terms are to be interpreted and implemented in our lives, there is near unanimity on the basic foundation of our globalized world. The gods, if anyone chooses to believe in them, have been forced to yield the stage to the political philosophers.

But is it possible to reclaim the sacred, to re-enchant the universe, to un-twilight the gods? In a world in which the arrow of time is said to parallel political "progress," such that there is

\footnotetext{
${ }^{1}$ Charles Taylor, A Secular Age (Cambridge, MA: Harvard University Press, 2007).

${ }^{2}$ See, e.g., The Dogmatic Constitution on the Church Lumen Gentium, November 21, 1964.
}

Jason Morgan jmorgan@ reitaku-u.ac.jp

1 Reitaku University in Kashiwa, Chiba, Japan even a right and a wrong side of history itself, is there any way to re-canopy the world with the presence of the divine, even allowing divinity being an idea that many in the secular milieu have dismissed? One glimpse of how such a reconfiguration of our modern mental framework might be effected comes from a recent book by Andrew Jones, Before Church and State: A Study of the Social Order in the Sacramental Kingdom of St. Louis $I X^{3}$. Jones, a Faculty Fellow at Franciscan University in Steubenville and an emerging light in the study of medieval Europe, has written a beautiful meditation about the realities of the spiritual and the political in thirteenth-century France.

Jones' finding is that secularity and modernity have basically reprogrammed the way we think about church and state. The state and the secular are now assumed to be almost the ground of existence for institutions that call themselves "religious" in inevitable counter-distinction to the secular. In St. Louis' time, however, Jones asserts, there was a holistic immersion in the divine. As Jones writes:

In the Middle Ages the 'secular' was integral to a conception of social reality that was thoroughly 'supernatural' in character. 'Justice' was a name for Christ, and the king was his vicar. The king's 'secular' justice was a direct participation in the construction of the City of God, and his legitimacy came only through his

\footnotetext{
${ }^{3}$ Andrew Willard Jones, Before Church and State: A Study of the Social Order in the Sacramental Kingdom of St. Louis IX (Steubenville, OH: Emmaus Academic, 2017).
} 
sacramental incorporation into the Body of Christ and the office that he held within it. He wielded the secular, temporal sword that had been bestowed on the Christian people by Christ himself. The temporal sword belonged to God. The 'religious' was not accidental to this world, and the kings were not the State. It was a sacramental world in which the material and the spiritual were everywhere and always present together. ${ }^{4}$

This is a noble insight and an argument worth pursuing at much greater length, but it also bears within it the contours of an unsettling question: What about societies that were never within Christendom in the first place? The "secular age" is hardly confined to the former borders of the Holy Roman Empire, so if one wishes to know what "the secular" is, then one will have to approach the problem from a variety of angles - as many angles, perhaps (and here again there is a danger of making "the secular" the center of a Copernican system of taxonomizing societies), as there were, and still are, ways of being in company with the divine.

Two other books besides Jones' give a glimpse of how sacred societies looked before "the secular" came to hold sway. Kiri Paramore's Japanese Confucianism: A Cultural History and Patrick Olivelle and Donald R. Davis, Jr., eds.', Hindu Law: A New History of Dharmaśāstra are both important studies of how societies looked far beyond the reach of Christendom, and far before the inversion, if Jones' theory may be applied here, of the sacred and the secular. ${ }^{5}$ The volume on Hindu law offers a new way of thinking about a world that has always been known to the West, and yet always unknown to it. There is much to be learned by considering how Indians once lived and the beliefs that cradled Indians in their daily interactions. In the case of Japanese Confucianism there is the added bonus of affording a view of how an ancient tradition made due when the Great Secularization swept up the Japanese archipelago.

I will take the Hindu law volume first. The Indian subcontinent has produced a torrent of intellectual riches over the past three and a half millennia, from the earliest stirrings of Rigveda transmission to the response by Indian scholars to European philosophers such as Kant and Heidegger. Unfortunately, almost all of this treasure trove is unknown to the West. There is so much to discover that even the most intrepid pilgrim can easily get overwhelmed. The Olivelle and Davis edited volume is a very good place to begin. In 37 short chapters dealing with every imaginable aspect of "Hindu" law (the term "Hindu" being contested as a latter-day construction of a thing that did not exist until the arrival of Western secularism), the Olivelle and Davis book is a window into a world very much unlike our own.

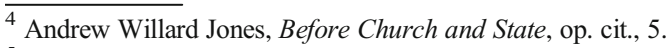

${ }^{5}$ Kiri Paramore, Japanese Confucianism: A Cultural History (Cambridge, UK: Cambridge University Press, 2016), Patrick Olivelle and Donald R. Davis, Jr., eds., Hindu Law: A New History of Dharmaśāstra (Oxford, UK: Oxford University Press, 2018).
}

For the brahmin, the practitioners of the rituals that bound the world of humans to the divine, the importance of the Dharmaśāstra was impossible to overstate. A rite done poorly could have cosmic ramifications. But a non-secular age is not necessarily not mundane. As Indian scholars of the dharma debated what was or was not permissible, what could or could not be done, they were also inadvertently forming the tradition that, for them, was a living way of being in the world. Calling Dharmaśāstra an "arbiter of orthodoxy in a polycentric tradition," Donald R. Davis, Jr., finds that "the most important function of the Dharmaśāstra has been its repeated claims to declare boundaries for a tradition that is famously unbounded". 6 Patrick Olivelle reaffirms the human side of the divine commerce: "The rules given in these texts [i.e., the Dharmaśāstra] promote virtuous and holy living". 7 Indeed, as Olivelle asserts in another chapter, humans were the model for other humans seeking to do right by the gods. "One can learn dharma by observing the practice of those who know and follow dharma just as one can learn good Sanskrit-so Patañjali would argue-by observing the speech patterns of particular individuals and communities". 8

Humans in pursuit of the divine thus inevitably deepen their shared humanity. But in a non-secular age, this is often done, not by "celebrating the self," as the American poet Walt Whitman sang, but by diminishing or denying it. Central to the life of ancient India as a whole, exemplified by the brahmin but pertaining throughout all the castes, was sacrifice, service, and the giving of gifts. As scholar David Brick explains, citing the great lawgiver Manu, in his seminal legal code, Manu (1.88-1.91) gives a standard account of the basic duties and lawful occupations of the four classical Indian social classes:

For Brahmins the Lord ordained teaching and learning the Veda, performing and officiating as sacrifices, and giving and receiving gifts. To the Kșatriya he assigned protecting his subjects, giving gifts, performing sacrifices, learning the Veda, and non-attachment to the sense-objects. To the Vaiśya he assigned guarding livestock, giving gifts, performing sacrifices, learning the Veda, trade, moneylending, and agriculture. And to the Sūdra the Lord assigned a single activity: service to the three previous social classes without resentment.

Passages expressing ideas virtually identical to those conveyed here by Manu are found in all of the surviving

\footnotetext{
$\overline{6}$ Donald R. Davis, Jr., "Introduction," in Patrick Olivelle and Donald R. Davis, Jr., eds., Hindu Law, op. cit., 8.

${ }^{7}$ Patrick Olivelle, "Social and Literary History of Dharmaśāstra," in Patrick Olivelle and Donald R. Davis, Jr., eds., Hindu Law, op. cit., 17.

${ }^{8}$ Patrick Olivelle, "Epistemology of Law: dharmapramāna," in Patrick Olivelle and Donald R. Davis, Jr., eds., Hindu Law, op. cit., 51.
} 
Dharmaśāstra works that precede his influential treatise, as well as in several subsequent ones. ${ }^{9}$

The rituals that are performed in a kind of supernatural synchronicity with this view of the universe and mankind's place within it were central to the life lived sacramentally in ancient India. The castes were not just social constructs, they were divinely ordained and thus structural components of the cosmos. Just as Dante's Divine Comedy is set in a Ptolemaic man-God-world wherein stars, seasons, and events are imbued with infinite significance, the world of the Indian devotee was, in many ways, the divine. Dante's variety of nondualism points to an even deeper assonance in India. ${ }^{10}$

A look at the Indian conception of "life-cycle rituals," or samskāra, will provide a good perspective on how this nondualism worked and was understood. As Alex Michaels points out:

In Western ritual theory, life-cycle rituals are often regarded as paradigmatic. This is partly due to Arnold Van Gennep's (1909) and, even more, Victor Turner's (1969) path-breaking studies. ${ }^{11}$ Both have introduced key terms for the discussion of rituals: 'rites de passage', 'rites de separation', 'rites de marge', and 'rites de agrégation', or 'liminality', 'communitas', 'social drama', and 'anti-structure'. The Indian term samskāra for life-cycle rituals is usually translated as 'transition rite', 'rite of passage', or 'sacrament', but these terms can only partially grasp its significance. For, as Brian K. Smith has emphasized, with the samskāras someone or something is made suitable, appropriate, or fit (yogya) for a holy purpose, for example, as a sacrificial offering. ${ }^{12}$ The gods accept only what is appropriate for them, that is, something correctly composed and perfect. Similarly, Jan Gonda defined samskāra as 'composing, making perfect, preparing properly and correctly with a view to a definite purpose'. 13

From a traditional Indian perspective, a samskāra is, therefore, not a divine punctuation, or an esoteric mysterium as the Greek mysterion (lit., secret) or the Latin sacramentum (originally 'oath of allegiance'). Nor

\footnotetext{
${ }^{9}$ David Brick "Gifting," in Patrick Olivelle and Donald R. Davis, Jr., eds., Hindu Law, op. cit., 197, citing Āpastamba Dharmasūtra 2.10.4-2.10.7, Baudhāyana Dharmasūtra 1.18.1-1.18.6, Gautama Dharmasūtra 10.1-10.2, Vasiștha Dharmasūtra 6.13-6.20, Vișnu Dharmasūtra 2.4-2.14, and Yājñavakya Dharmaśāstra 1.118-1.120.

${ }^{10}$ On Dante's "architectonics," see Archibald T. MacAllister, "Introduction," in Dante Alighieri, tr. John Ciardi, The Divine Comedy: The Inferno, The Purgatorio, The Paradiso (New York: New American Library, 2003).

${ }^{11}$ Victor Turner, The Ritual Process: Structure and Anti-Structure (London: Routledge \& Kegan Paul, 1969), Arnold van Gennep, Les rites de passage (Paris: Éditions A. et J. Picard, 1909).

12 Brian K. Smith, Reflections on Resemblance, Ritual, and Religion (New York: Oxford University Press, 1989), 86.

13 Jan Gonda, Vedic Ritual: The Non-Solemn Rites (Leiden: Brill, 1980), 364.
}

is it just the celebration of a phase of life. It is rather a ritual identification with the absolute or the Veda. In the initiation rite, for instance, the son is equated with the father, the Veda, the sacrifice and the fire; and only through such an identification can he achieve immortality. If this substitution is perfect (samskrta), the rite works ex opere operato, through the action itself and the power of the ritual equivalence, independent of the mental state of the adept. ${ }^{14}$

Here we may recall the ex opere operato teaching of the Catholic Church, according to which the priest is the vehicle for a rite which works somehow through him and yet independently of his mental or spiritual disposition. ${ }^{15}$ In this vestige of a medieval sacramentality in the modern world we see, perhaps, a glimmer of what the samskāra was in ancient India.

A very different paradigm emerges reading Kiri Paramore's book on Confucianism in Japan. Paramore begins by defining "Confucianism," which, as with the term "Hindu," is hotly contested. (Whether "Confucianism" was, further, a religion, a philosophy, neither, or both is yet another field of battle in the definitional conflict.) For Paramore:

Confucianism is a constellation of ways of thinking, writing, behaving, and practicing brought together and theorized as a single unified tradition closely associated with the imperial state during the Chinese Han dynasty (206 BCE-220 BCE). The word Confucianism today is also commonly used to refer to the intellectual and religious factions active before the Han dynasty, identified with the Chinese word 'ru' [儒] and with certain historic personages including Confucius.

Paramore is of the opinion that:

Han dynasty political thinkers used traces of writings associated with these earlier factions to manufacture a larger, more cohesive textual apparatus and ideology which became Confucianism. Confucianism was then posited post ipso facto as a historical tradition, especially in the official histories of the Han dynasty, the Books of Han, edited by Ban Gu (32-92 CE). To some extent, Confucianism as it emerged in the common era can thus be seen as the

\footnotetext{
${ }^{14}$ Alex Michaels, "Ritual," in Patrick Olivelle and Donald R. Davis, Jr., eds., Hindu Law, op. cit., 439.

${ }^{15}$ See Catechism of the Catholic Church, Part Two, "The Celebration of the Christian Mystery, Section Two, "The Seven Sacraments of the Church," Chapter Three, "The Sacraments at the Service of Communion," Article 6, "The Sacrament of Holy Orders," VII, "The Effects of the Sacrament of Holy Orders," paragraph 1584, citing St. Augustine, In Jo. Ev. [Tractates on the Gospel of John] 5, 15: PL 35, 1422. See also Cathy Caridi, "Pedophile Priests and Holy Orders," Canon Law Made Easy, August 17, 2017 https:// canonlawmadeeasy.com/2017/08/17/pedophile-priests-and-sacramentalvalidity/ Accessed January 4, 2020.
} 
ideological construction of Han officials like Ban Gu. ${ }^{16}$ Its roots were then projected back into the 'distant past'. ${ }^{17}$

There are similarities between a Dharmaśāstric immanence and this Paramorian understanding of Confucianism, in particular the notion of Confucianism as a tradition which human beings have participated in shaping. For example, Paramore epigrams his book with the classical Chinese phrase 自我作古 (zi wo zuo gu, "antiquity is constructed by us"), coined by Tang Confucian Liu Zhiji (661-721) and later picked up by Tokugawa Confucianist physician Kagawa Shūan (16831755, also known as Shūtoku and Nobunori) and Meiji modernizer Fukuzawa Yukichi (1835-1901). All three men had their reasons for emphasizing the presence of the present in the shadow of the past.

But there are also differences. Paramore's focus is on Japanese Confucianism, and he is anxious to show that Confucianism has been a foil in the creation of a Japanese kind of modernity, or anti-modernity, which for Paramore is deeply political. For there to be a Japanese Confucianism, there must be a Japan - a polity and not a philosophy or a religion - and so by juxtaposing the two things Paramore arrives at what would appear to be yet another secularist reading of a more sacred way of existing. Just as Ban Gu invented Confucianism in the Han, Paramore is saying, Japanese scholars and elites contested and formed their own versions of Confucianism to suit the needs of the day. (On the paradigm Paramore has set up, his subjects could, conceptually, do little other.) In the text that the Master's students recorded of his putative sayings, Confucius spends precious little time discussing the divine, to be sure. But Confucius does have an idea of Heaven (tian) as a kind of moral arbiter or force for justice and the good. Overly political understandings of Confucianism (to be separated, of course, from Confucius himself, as Paramore does) may end up eliding more of this dimension of the Master's thought than is necessary. Modernity can, after all, be a self-fulfilling prophecy.

St. Louis, the Vedic sages, Confucius and the Confucians - what do all of these tell us about the prospects for reanimating the divine in the secular world, or at the very least for understanding the past in some way other than a secularist sub species aeternitatis? (Recalling that the author of this phrase is Baruch Spinoza reminds us that there is also a Jewish counter-modernity, or modernity-skepticism, which, although beyond the scope of this little essay, is at least as vibrant as the Confucian and Dharmaśāstric varieties.) Is the Taylorian secular age a permanent feature of human life? Has history, in that sense, really come to a Hegelian resting place, the secular having pulled a final cunning-of-reason by displacing Geist?

This is a question not without import. As challenges to the political Hegelianism of the late twentieth century mount, and as the age of Fukuyama's "end of history" and of the seeming victory of liberalism as a true world philosophy approaches what appears to be a "twilight of the idols" of its very own, human beings are again confronted with the most basic of questions: Who are we? Who made us? What are we doing on this planet, and how should we live? These are questions that a secular age brings into bold relief, but that a secular age leaves us with no possibility of answering. As R.R. Reno lays out in his new book on the reassertion of ancient loyalties that the global regime preferred to treat as outmoded, or at best atavistic and doomed to eventual obsolescence, we are now returning to an age of the "strong gods," perhaps a precursor to a world that will look increasingly less like Taylor's secularist empire, and more like the world revealed in the Dharmaśāstra, or the Analects, or the Psalms. ${ }^{18}$

Publisher's Note Springer Nature remains neutral with regard to jurisdictional claims in published maps and institutional affiliations.

Jason Morgan is associate professor in the Faculty of Global Studies at Reitaku University in Japan. His study of Suehiro Izutarō and the lawand-society movement in Japan was published by Cambria Press in 2020, and an edited volume on East Asia and the Cold War is due out from Routledge in 2021. Morgan's essays have appeared at JAPAN Forward, Japan Review, Dao, University Bookman, Human Life Review, Reitaku Review, Studia Gilsoniana, the Fellowship of Catholic Studies Quarterly, New Oxford Review, Chronicles, The Remnant, Inter-Asia Cultural Studies, and elsewhere.

\footnotetext{
$\overline{16}$ citing Kojima Tsuyoshi, Higashi Ajia no jukyō to rei (Tokyo: Libretto, 2013), 22-4.

${ }^{17}$ Paramore, Japanese Confucianism, op. cit., 5.
}

\footnotetext{
${ }^{18}$ R.R. Reno, Return of the Strong Gods: Nationalism, Populism, and the Future of the West (Washington, DC: Gateway Editions, 2019)
} 